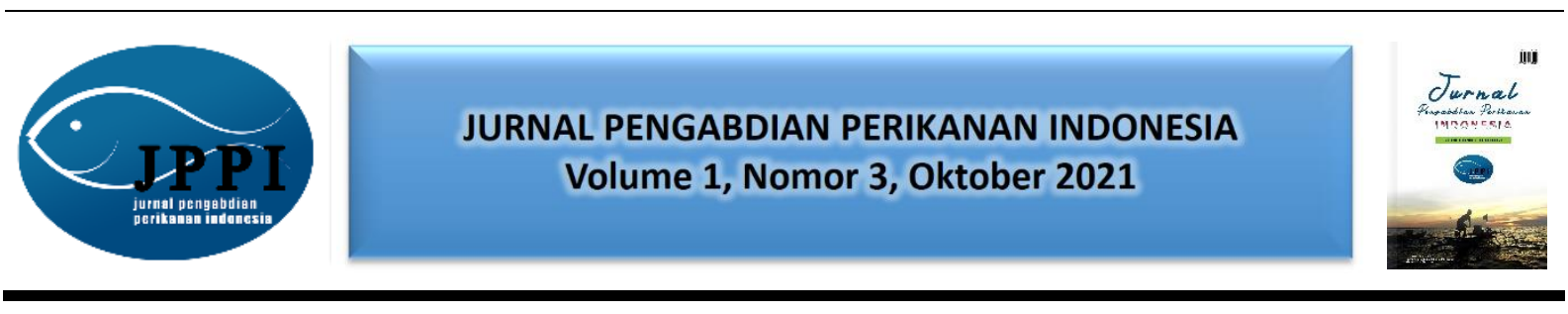

\title{
SOSIALISASI PENANGANAN KESEHATAN RUMPUT LAUT (Eucheuma cottoni) DALAM PENGEMBANGAN EKONOMI MASYARAKAT PESISIR PANTAI KALUKU KOTA BAUBAU DI ERA PANDEMI COVID-19
}

\author{
Ismail Failu ${ }^{1}$, Bahtiar Hamar' ${ }^{1}$, Abdul Hadi Bone ${ }^{1}$, Azelia Monica Azizu $^{2}$ \\ ${ }^{1}$ Program Studi Pengelolaan Sumberdaya Perairan Universitas Muhammadiyah Buton ${ }^{2}$ Program Studi \\ Agribisnis Universitas Muhammadiyah Buton
}

Jalan Betoambari No. 36 Kota Baubau Sulawesi Tenggara. Telp. (0402)2822913 Fax. (0402) 2822913

*Alamat korespondensi : ismailfailu86@gmail.com

(Tanggal Submission: : 15 September 2021, Tanggal Accepted : 31 Oktober 2021)

\begin{abstract}
Keyword: Abstrak :
Kesehatan Pesisir pantai Kaluku terletak di wilayah Kota Baubau mempunyai sumberdaya laut yang rumput sangat melimpah, salah satu diantaranya adalah rumput laut. Masyarakat pantai Kaluku laut, pesisr didominasi oleh mata pencaharian sebagai nelayan yang aktivitasnya membudidayakan pantai rumput laut, namun kendala yang dihadapi adalah adanya pengaruh pada pertumbuhan kaluku, kota rumput laut yang disebabkan oleh hama penyakit yang menempel dan kurangnya pengetahuan tentang penggunaan teknologi pengembangan pertumbuhan rumput laut. Bau Bau Oleh karena itu, kegiatan Pengabdian Kepada Masyarakat (PkM) ini bertujuan memberikan pengetahuan kepada masyarakat terhadap penanganan kesehatan rumput laut secara efektif guna meningkatkan taraf pendapatan Ekonomi Masyarakat Pesisir Pantai Kaluku Kota Baubau melalui produksi rumput laut di era pandemi Covid-19. Kegiatan PkM ini dimulai dengan konsultasi ke Pemerintah Desa dan koordinasi dengan pihak mitra, kemudian dilanjutkan dengan sosialisasi dan pelatihan penanganan kesehatan rumput laut. Hasil dari kegiatan adalah terbentuknya mitra produksi yang memproduksi rumput laut beserta pemasarannya. Selain itu, produk rumput laut akan dimanfaatkan sebagai bahan utama pembuatan oleh-oleh khas Kota Baubau, Kampung Lingkungan Kaluku.
\end{abstract}

Panduan Sitasi (APPA $7^{\text {th }}$ edition) :

Failu, I., Hamar, B., Bone, A.H., \& Azizu, A.M. (2021). Sosialisasi Penanganan Kesehatan Rumput Laut (Eucheuma Cottoni) Dalam Pengembangan Ekonomi Masyarakat Pesisir Pantai Kaluku Kota Baubau Di Era Pandemi Covid-19. Jurnal Pengabdian Perikanan Indonesia, 1 (3), 240-247. http://doi.org/ 10.29303/jppi.v1i3.495 


\section{PENDAHULUAN}

Rumput laut merupakan komuditas utama di indonesia, artinya subsektor perikanan budidaya menghasilkan barang dalam jumlah yang cukup besar setiap tahunnya. Tanpa komoditas ini, hasil perikanan budidaya akan tertinggal dan tidak mungkin memenuhi target produksi tahunan, meski pandemi COVID-19 terus menyebar dan mengancam menjadi pandemi global, namun tidak menjadi faktor penghambat dalam memproduksi rumput laut yang harganya tetap stabil dan memenuhi target pasar. Produksi rumput laut terus meningkat, baik dari segi kualitas maupun kuantitas.

Kota Baubau memiliki garis pantai sepanjang \pm 42 kilometer yang berpotensi menjadi penghasil rumput laut. Selain itu, wilayah sekitarnya, yaitu perairan Kabupaten Muna, Buton, Buton Utara, Buton Tengah, Buton Selatan, dan Bombana, menawarkan potensi besar sebagai pembudidaya rumput laut. Memang, Provinsi Sulawesi Tenggara telah diakui sebagai Pusat Pertumbuhan Daerah Sulawesi (BKPRS) sejak tahun 2005, dengan Kota Baubau sebagai outlet utama pengembangan komoditas tersebut.

Wilayah pengembangan budidaya rumput laut di Kota Baubau tersebar di beberapa desa pesisir, antara lain Kelurahan Palabusa, Kalia-lia, Kolese, dan Lowu-Lowu (Kecamatan Bungi), Kelurahan Lakologou, Kelurahan Waruruma, Sukanaeyo, dan Liwuto (Kecamatan Kokalukuna), Kelurahan Naganganaumala, Wameo, Tarafu, dan Bone-Bone (Kecamatan Murhum), serta Kelurahan Katobengke dan Sulaa (Kecamatan Betoambari). Luas perair yang dapat manfaatkan untuk budidaya rumput laut sekitar $960 \mathrm{Ha}$ di sepanjang garis pantai prospektif, yaitu sekitar $9 \mathrm{Km}$ untuk Kecamatan Murhum dan Betoambari Namun, hanya 111,6 Ha.

Masyarakat pesisir terdiri dari individu-individu yang tinggal di wilayah pesisir dan yang mata pencahariannya secara langsung bergantung pada pemanfaatan sumber daya laut dan pesisir. Pemerintah mempromosikan budidaya rumput laut sebagai salah satu kegiatan ekonomi yang akan membantu meningkatkan wilayah pesisir (Pratiwi, 2018). Salah satu kegiatan ekonomi yang sedang digalakkan pemerintah dalam pengembangan wilayah pesisir adalah budidaya rumput laut.

Pengembangan budidaya rumput laut merupakan salah satu inisiatif pemberdayaan masyarakat pesisir, karena barang yang dihasilkan memiliki aplikasi yang beragam, (2) tersedianya lahan yang luas untuk budidaya, dan (3) teknologi yang dibutuhkan sederhana (Kementerian Kelautan dan Perikanan).

Masalah paling umum yang dihadapi pembudidaya adalah kualitas produk yang tidak diprioritaskan, penanganan hama rumput laut yang tidak tepat dan metode penanaman yang sesuai masih kurang. Hal ini disebabkan masih banyaknya petani yang belum mengetahui teknik dan teknologi yang efektif dan efisien dalam pengembangan budidaya rumput laut. Teknik long line budidaya rumput laut masih digunakan di wilayah tersebut untuk produksi rumput laut. Penggunaan teknik long line memiliki kelemahan yaitu predator seperti ikan baronang (Sigananus spp.) dan penyu hijau (Chelonia midas), bulu babi (Diadema sp.) dan bintang laut (Protoneostes) mudah menyerang rumput laut sehingga menyebabkan kerusakan pada thallus rumput laut. Bakteri akan masuk ke dalam tubuh melalui luka dan menyebabkan infeksi sekunder. Penumpukan pertumbuhan bakteri di thallus akan menyebabkan thallus menjadi putih dan menjadi rapuh dalam penampilan. Selain itu, komponen tersebut mudah rusak, dan akibatnya jaringan menjadi lembek, yang secara tidak langsung akan membantu perkembangan penyakit. Jaringan menjadi putih ketika infeksi mempengaruhi pangkal thallus, batang, atau ujung thallus remaja. Pada umumnya penyebarannya terjadi secara vertikal atau horizontal (melalui perantara air) tergantung keadaan. Karena thallus rumput laut tidak dapat melakukan fotosintesis, infeksi akan semakin parah akibat serangan epifit yang menghalangi sinar matahari mencapai thallus rumput laut. (Santoso dan Nugraha, 2008). 
Tujuan dari pengabdian kepada masyarakat yaitu untuk meningkatkan pengetahuan tentang pengelolaan kesehatan rumput laut sehingga dapat meningkatkan taraf pendapatan Ekonomi Masyarakat Pesisir Pantai Kaluku Kota Baubau Di Era Pandemi Covid-19

Manfaat kegiatan pengabdian masyarakat diharapkan dapat membantu masyarakat Lingkungan Kaluku Kelurahan Bone-Bone Kota Baubau, sehingga dapat mengetahui bagaimana cara penanganan penyakit rumpur laut serta untuk meningkatkan taraf pendapatan ekonomi para pembudidaya rumput laut.

\section{METODE KEGIATAN}

Metode pelaksanaan kegiatan pengabdian kepada masyarakat dilaksanakan melalui beberapa tahapan yaitu:

1. Tahap Perizinan dan Koordinasi Mitra, kegiatan dilakukan dengan meminta izin kepada pemerintah desa setempat dan berkoordinasi dengan salah satu warga kampung nelayan pesisir pantai Kaluku Kota Baubau untuk mendapatkan informasi jelas tentang situasi dan kondisi lapangan.

2. Tahapan Survey, kegiatan dilakukan dengan pendekatan wawancara langsung untuk mengetahui berbagai persoalan yang dihadapi oleh masyarakat Lingkungan Kaluku Kelurahan Bone-Bone Kota Baubau.

3. Tahapan Sosialisasi Program, kegiatan yang dilakukan antara lain : a) Mensosialisasikan program kegiatan penanganan kesehatan rumput laut; b) Pembentukan kelompok untuk pembinaan lapangan. Output dari kegiatan ini adalah terbentuknya kelompok wirausaha dalam penanganan panen dan pasca panen hingga produksi rumput laut.

4. Tahapan Pendampingan, merupakan kegiatan pendampingan dalam bentuk bantuan dan bimbingan saat pelaksanaan program dan pendampingan pemasaran rumput laut. Kegiatan ini bertujuan agar kelompok wirausaha (mitra) lingkungan Kaluku Kelurahan Bone-bone Kota Baubau mampu menghasilkan rumput laut yang berkualitas dan mampu melaksanakan pembuatan oleh-oleh dari bahan dasar rumpu laut secara berkala dengan pendampingan.

5. Tahap Evaluasi, kegiatan ini dilakukan untuk mengevaluasi seluruh kegiatan dari awal sampai akhir dengan tujuan mendapatkan hasil kinerja kelompok mitra dalam menangani kesehatan rumput laut dan mampu mengelolah rumput laut menjadi sebuah produk yang bernilai ekonomis. Kegiatan ini berupa pengisian kuisioner (angket) evaluasi pelaksanaan sosialisasi.

\section{HASIL DAN PEMBAHASAN}

Pemberdayaan masyarakat merupakan serangkaian kegiatan untuk memperkuat kekuasaan kelompok masyarakat termasuk individu yang mengalami kemiskinan. Sebagai tujuan, pemberdayaan menunjuk pada keadaan atau hasil yang ingin dicapai oleh sebuah perubahan sosial yaitu masyarakat yang berdaya, mempunyai pengetahuan dan kemampuan dalam memenuhi kebutuhan hidup yang bersifat fisik, ekonomi, maupun sosial (Rohmah, 2017:4). Pemberdayaan masyarakat dilakukan melalui pembentukan kelompok wirausaha nelayan yang memiliki tujuan untuk menciptakan sebuah lapangan pekerjaan bagi nelayan untuk memenuhi kebutuhan hidup selama masa pandemi Covid-19. Kegiatan pemberdayaan ini sangat penting untuk meningkatkan sistim perekonomian masyarakat pesisir khususnya di lingkungan Kaluku Kelurahan Bone-Bone Kota Baubau. 


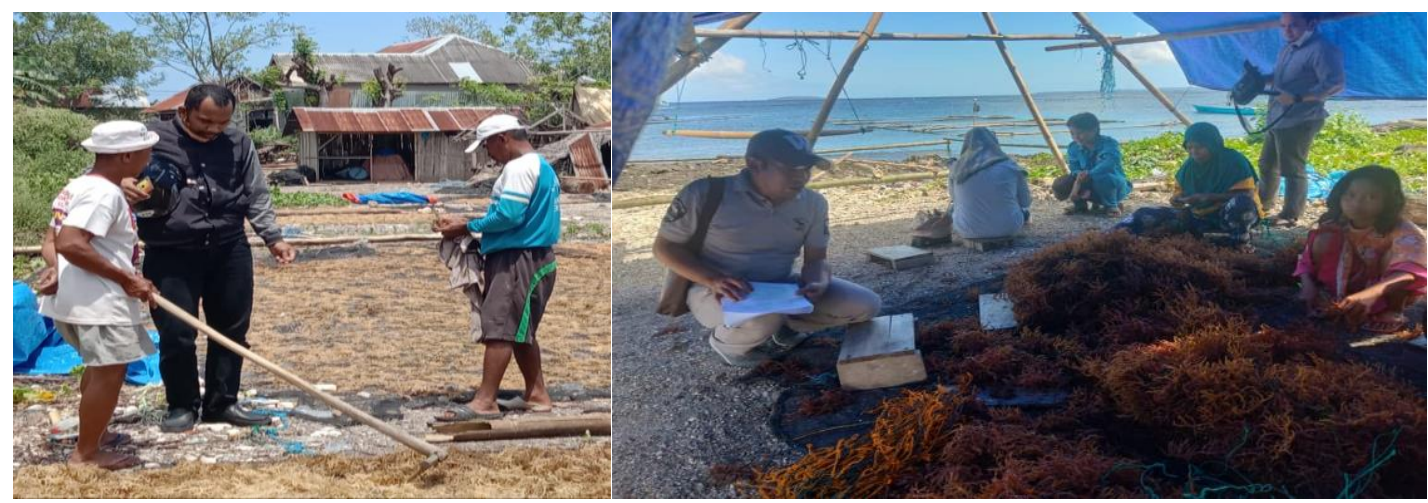

Gambar 1. Foto Survey atau Wawancara Langsung Bersama Masyarakat

Pemberdayaan masyarakat meliputi proses sosialisasi dan pendampingan untuk kelompok wairausaha nelayan rumput laut yang bertujuan untuk melatih para masyarakat nelayan dalam menangani kesehatan rumput laut akibat hama penyakit sehingga dampaknya dapat meningkatkan pengetahuan berwirausaha dan mendapatkan hasil pendapatan yang diharapkan. Minimnya pengetahuan yang nelayan punya merupakan salah satu faktor terciptanya pemberdayaan (Imaniar, 2017;65).

Sosialisasi diawali dengan kegiatan observasi warga lingkungan kaluku Kelurahan Bone-Bone. Observasi ini bertujuan untuk menentukan anggota mitra (kelompok wirausaha) yang dinilai kurang mampu menguasai penanganan hama penyakit rumput laut, kemudian dilakukan pembentukan kelompok yang sasarannya pada pembudidaya rumput laut. Setelah observasi dilakukan maka dilakukan pertemuan yang dihadiri oleh Lurah Bone-bone, sekretaris lurah, serta masyarakat pesisir pembudidaya rumput laut untuk saling bertukar informasi terkait penangan hama penyakit dan pengembangan teknologi pertumbuhan rumput laut. Seminar ini di awali dengan pemaparan analisis usaha budidaya rumput laut, guna menumbuhkan semangat jiwa wira usaha masyarakat pesisir. Kemudian di lanjutkan dengan seminar kedua yakni bagaimana cara penanganan hama dan penyakit yang menempel pada rumput laut sehingga pasca panen tidak gagal serta mutu produksi tetap berkualitas dan mempunyai nilai hasil lebih baik.

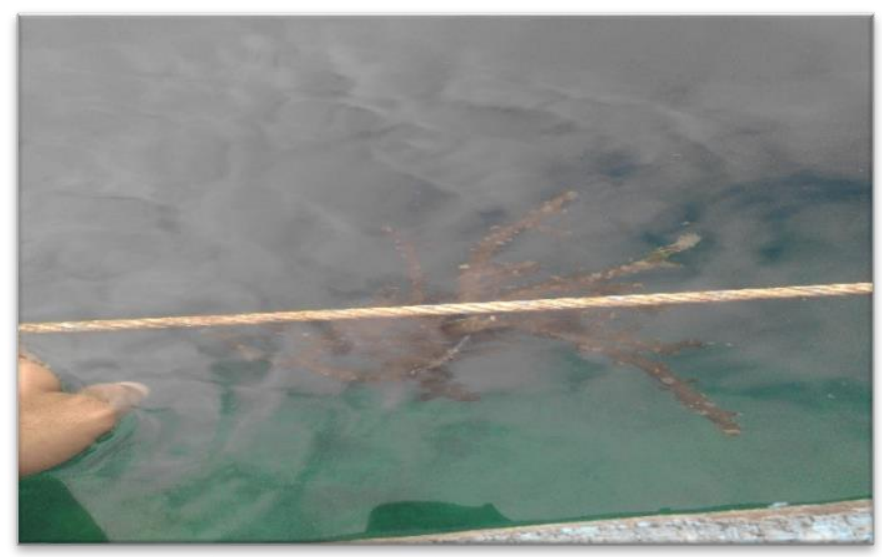

Gambar 2. Foto Analisa Penanganan Hama Penyakit Pada Rumput Laut

Pengabdian Kepada Masyarakat yang dilakukan oleh Tim Program Studi Pengelolaan Sumberdaya Perairan Universitas Muhammadiyah Buton yang diberikan penyuluuhan kepada kelompok mitra para pembudidaya rumput laut Kelurahan Bone-bone Lingkungan Kaluku Kota Baubau adalah sebagai berikut : 
1. Pemetaan syarat pemiliihan lokasi budidaya rumput laut

Usaha budidaya rumput laut sangat dipengaruhi oleh banyak faktor baik internal maupun eksternal. Olehnya itu maka penetapan Lokasi sangatlah penting dan mutlak diperlukan demi kesinambungan Usaha Budidaya. Beberapa kegiatan budidaya rumput laut baik skala kecil maupun besar banyak mengalami kegagalan akibat pemilihan lokasi yang tidak tepat. Pada Wilayah yang penataan ruangnya belum ada atau tidak jelas akan senantiasa akan menyebabkan konflik pemanfaatan ruang terutama aktifitas yang sangat saling berpengaruh tetapi kegiatannya berdampingan

2. Syarat Pemilihan Lokasi

- Mudah dijangkau

- Dasar perairan terdiri dari pasir karang dan pecahan karang

- Salinitas 30-35 Permil

- Suhu air $25-29^{\circ} \mathrm{C}$

- $\mathrm{pH}$ air berkisar antara 6-9 dan optimalnya 7,5-8,0

- Perairan bersih dan jernih dengan kecerahan $5 \mathrm{~m}$ atau lebih

- Kedalaman minimal $50 \mathrm{Cm}$ (lepas dasar)

- Arus Cukup $(0,2-0,4 \mathrm{~m} /$ detik

- Terlindung dari arus dan hempasan ombak yang keras

- Air tidak tercemar limbah industri

- Tidak banyak predator/hama dan kompetitor/pesaing RL

- Bukan merupakan jalur pelayaran

3. Perawatan Selama Pemeliharaan

- Mengganti bibit yang hilang atau lemah

- Menggoyang goyang atau mencabuti langsung lumut atau organisme penempel pada tali ris

- Memindahkan material terapung di sekitar lokasi budidaya

- Mengikat ulang tali ris yang hilang atau lepas

- Mengganti pelampung atau peralatan yang hilang atau rusak

4. Monitoring

- Mencatat perkembangan pertumbuhan selama penanaman

- Menyiapkan peralatan monitor kualitas perairan 
5. Monitoring Selama Penanaman

Tabel 1. Monitoring Selama Budidaya Rumput laut

\begin{tabular}{|c|c|c|c|c|c|c|c|c|c|c|c|c|c|c|}
\hline \multirow{2}{*}{ No } & \multirow{2}{*}{ Permasalahan } & \multicolumn{12}{|c|}{ BULAN } & \multirow{2}{*}{$\begin{array}{c}\text { Pemecahan } \\
\text { Masalah }\end{array}$} \\
\hline & & 1 & 2 & 3 & 4 & 5 & 6 & 7 & 8 & 9 & 10 & 11 & 12 & \\
\hline 1 & Musim ice-ice & & & & & & & & & & & & & $\begin{array}{l}\text { Pilih bibit } \\
\text { tahan } \\
\text { penyakit } E \text {. } \\
\text { denticulatum } \\
\text { Istirahat } \\
\text { tanam }\end{array}$ \\
\hline 2 & $\begin{array}{l}\text { Musim hujan } \\
\text { (Angin dan } \\
\text { Ombak besar) }\end{array}$ & & & & & & & & & & & & & $\begin{array}{l}\text { Tanaman } \\
\text { dipindahkan } \\
\text { ke tempat } \\
\text { teduh } \\
\text { Tanam bibit } \\
\text { E. } \\
\text { denticulatum } \\
\text { Batasi } \\
\text { jumlah } \\
\text { bentangan }\end{array}$ \\
\hline 3 & $\begin{array}{l}\text { Musim } \\
\text { kemarau }\end{array}$ & & & & & & & & & & & & & $\begin{array}{l}\text { Kedalaman } \\
\text { bentangan } \\
\text { diturunkan. } \\
\text { Posisi RL min } \\
50 \mathrm{~cm} \text { dari } \\
\text { permukaan } \\
\text { air }\end{array}$ \\
\hline 4 & $\begin{array}{l}\text { Musim gulma } \\
\text { (Lumut) }\end{array}$ & & & & & & & & & & & & & $\begin{array}{l}\text { Bersihkan } \\
\text { gulma dan } \\
\text { goyang } \\
\text { bentangan } \\
\text { tanaman } \\
\text { Pindahkan } \\
\text { ke lokasi } \\
\text { berarus }\end{array}$ \\
\hline 5 & $\begin{array}{l}\text { Pertumbuhan } \\
\text { kerdil }\end{array}$ & & & & & & & & & & & & & $\begin{array}{l}\text { Ganti bibit } \\
\text { dari lokasi } \\
\text { berbeda } \\
\text { Bentangan } \\
\text { dijarangkan }\end{array}$ \\
\hline
\end{tabular}

Berdasarkan tabel 1, dapat dilihat beberapa permasalahan yang dihadapi oleh pembudidaya rumput laut selama musim penanaman, pada kondisi rumput laut yang terserang penyakit ice-ice, maka pemecahan masalahnya yaitu pemilihan bibit yang tahan terhadap penyakit, untuk kondisi 
musim hujan (ombak besar dan angin kencang), hal terpenting yang perlu dilakukan adalah mencari lokasi yang aman dari ombak besar dan mengurangi jumlah bentangan. Sedangkan pada musim kemarau dan musim gulma (lumut) hal yang perlu dilakukan adalah dengan menambah kedalaman bentangan $\pm 50 \mathrm{~cm}$ dari permukaan air, serta rajin melakukan pembersihan rumput laut dari gulmagulma penganggu yang dapat menyebabkan pertumbuhan rumput laut terganggu, serta menempatkan rumput laut pada perairan yang memiliki kondisi perairan yang berarus sedang. Menurut Doty (1987) penyakit ice-ice merupakan penyakit yang bersifat musiman dimana hal tersebut dapat disebabkan oleh perubahan kualitas air akibat perubahan musim, baik terjadi pada musim hujan dan musim kemarau, yang dapat menyebabkan perubahan suhu dan salinitas, $\mathrm{pH}$. Perubahan lingkungan pada musim ekstrim di perairan merupakan akumulasi sejumlah penyebab pemicu timbulnya penyakit.

6. Monitoring kondisi budidaya rumput laut

Tabel 2. Monitoring kondisi budidaya rumput laut

\begin{tabular}{|c|c|c|c|c|c|}
\hline & $\begin{array}{c}\text { Apakah } \\
\text { dimakan } \\
\text { ikan? }\end{array}$ & $\begin{array}{l}\text { Apakah ada } \\
\text { ice-ice? }\end{array}$ & $\begin{array}{c}\text { Apakah ada } \\
\text { gulma ? }\end{array}$ & Rekomendasi & \\
\hline Kondisi 1 & Tidak & Tidak & Tidak & $\begin{array}{l}\text { Optimalkan } \\
\text { jumlah } \\
\text { bentangan }\end{array}$ & \\
\hline Kondisi 2 & Tidak & Tidak & $\mathrm{Ya}$ & $\begin{array}{l}\text { Pantau } \\
\text { secara rutin } \\
\text { Bersihkan } \\
\text { gulma }\end{array}$ & \\
\hline Kondisi 3 & Tidak & $\mathrm{Ya}$ & $\mathrm{Ya}$ & $\begin{array}{l}\text { Pindah ke } \\
\text { lokasi } \\
\text { berarus } \\
\text { Tanam jenis } \\
\text { tahan } \\
\text { penyakit }\end{array}$ & \\
\hline Kondisi 4 & $\mathrm{Ya}$ & $\mathrm{Ya}$ & $\mathrm{Ya}$ & $\begin{array}{l}\text { Panen } \\
\text { Istirahat } \\
\text { tanam }\end{array}$ & \\
\hline
\end{tabular}

Tabel 2, dapat dilihat pada kondisi 1 (satu) dan kondisi 2 (dua) merupakan kondisi dimana rumput laut terbebas dari hama dan penyakit sehingga direkomndasi untuk melakukan pengoptimalan jumlah bentangan rumput laut serta melakukan pemantauan secara rutin terhadap gangguan gulma, yang dapat menyebabkan terganggunya pertumbuhan rumput laut. Sedangkan pada kondisi 3 (tiga) dan kondisi 4 (empat) merupakan kondisi dimana rumput laut berada pada kondisi terserang penyakit dan adanya hama pengganggu berupa ikan dan gulma. Menurut Santoso dan Nugraha (2008) faktor pemicu lainnya dapat menyebabkan penyakit ice-ice adalah disebabkan oleh serangan hama seperti penyu hijau (Chelonia midas) dan ikan baronang (Siganus spp) yang dapat mengakibatkan luka pada 
thallus, kondisi ini dapat di perparah dengan adanya lumut atau gulma yang dapat menghalangi sinar matahari sehingga tidak ada proses fotosintesa. Sehingga pada kondisi tersebut direkomendasikan untuk melakukan langkah-langkah pencegahan berupa mencari lokasi yang berarus sehigga hama penganggu seperti lumut atau gulma tidak mudah melengket pada rumput laut, mengganti dengan tanaman yang baru yang tahan terdapat penyakit sampai dengan melakukan pemanenan dan istirahat tanam, untuk menghindari kerugian.

\section{KESIMPULAN DAN SARAN}

Dari uraian di atas dapat ditarik kesimpulan sebagai berikut :

a. Kegiatan ini dapat membentuk sebuah lapangan pekerjaan baru untuk nelayan pembudidaya rumput laut di Lingkungan Kaluku Kelurahan Bone-Bone Kota Baubau melalui pembentukan kelompok wirausaha;

b. Kegiatan ini dapat memberikan wawasan baru bagi nelayan pembudidaya rumput laut dalam menangani permasalahan penyakit hama yang menempel pada rumput laut;

c. Kegiatan ini dapat meningkatkan perekonomian bagi keluarga nelayan khususnya di Lingkungan Kaluku Kelurahan Bone-Bone Kota Baubau.

Kegiatan ini disarankan tetap berjalan dengan baik dengan membentuk kelompok usaha rumput laut yang lebih besar dengan memanfaatkan teknologi tepat guna untuk mengatasi masalah hama penyakit yang menempel pada rumput laut, sehingga pada musim tanam berikutnya masyarakkat pesisir akan merubah pola budidaya yang selanjutnya akan dapat meningkatkan perekonomian dan kesejahteraan keluarga nelayan.

\section{DAFTAR PUSTAKA}

Anggadiredja, J.T., Zatnika, A., Purwoto, H., Istini, S., 2006. Rumput Laut. Penebar Swadaya. 25 hal. Doty, M. S. (1987). The production and use of Eucheuma. In M. S. Doty, J. F. Caddy, \& B. Santelices (Eds.), Case studies of seven commercial seaweed resources. FAO fish. tech. paper, 281 (pp. 123-164). Rome: FAO.

Hidayati, W. 2009. Analisis Struktur, Perilaku dan Keragaan Pasar Rumpu Laut Provinsi Sulawesi Selatan. TESIS. Sekolah Pascasarjana Institut Pertanian Bogor. Bogor.

Imaniar, Dimas. 2017. Pemberdayaan Masyarakat Pesisir Melalui Pemanfaatan Pengelolaan Limbah dan Cangkang Kerang. JURNAL ILMIAH ILMU_ILMU SOSIAL DAN HUMANIORA. 1693-8925

Rohmah, Nurul Lailatul. 2017. Pemberdayaan Perempuan Pesisir Dalam Pengelolaan Ikan Laut Untuk Meningkatkan Ekonomi Keluarga. Skripsi. Program Sarjana Ekonomi Syariah Institut Agama Islam Negeri Purwekerto, Purwekerto.

Pratiwi, E. T., Abdullah, R., \& Abdullah, L. O. D. (2018). Training of Financial Management on Society Self-Helping Agency at Kelurahan Palabusa, Baubau City, Southeast of Sulawesi. Seminar Nasional dan The 5th Call For Syariah Paper (SANCALL) 2018.

Santoso, L. dan Y. T. Nugraha. 2008. Pengendalian Penyakit Ice-Ice untuk Meningkatkan Produksi Rumput Laut Indonesia. Jurnal Saintek Perikanan, 3 (2) : 37- 43. 